\title{
Flora of Espírito Santo, Brazil \\ Flora of Itaúnas State Park, Espírito Santo, Brazil: Cactaceae
}

\author{
Álvaro Nepomuceno ${ }^{1,2,5}$, Victor Santos Miranda ${ }^{1,3}$ \& Anderson Alves-Araújo ${ }^{1,4}$
}

\begin{abstract}
The present work, which is part of a series of taxonomic monographs, aims to provide useful taxonomic features for distinguishing species of Cactaceae from Itaúnas State Park-Brazil. After performing field expeditions and observations, and analysis of herbaria vouchers, a total of five species of Cactaceae is herein recorded: Brasiliopuntia brasiliensis (Least Concern), Cereus fernambucensis subsp.fernambucensis (Least Concern), Melocactus violaceus subsp. violaceus (Vulnerable), Pereskia aculeata (Least Concern), and Pilosocereus arrabidae (Near Threatened). Leaf (when present) and cladodes morphology, and presence or absence of cephalium are the most useful characters to specific delimitation. Key identification, descriptions, photographs, taxonomic comments, geographic distribution and habitat data are herein provided.
\end{abstract}

Key words: Atlantic Forest, cacti, Caryophylalles, Restinga, taxonomy.

\section{Resumo}

O presente trabalho, que faz parte de uma série de monografias taxonômicas, visa fornecer características taxonômicas úteis para distinguir espécies de Cactaceae do Parque Estadual de Itaúnas-Brasil. Após a realização de expedições e observações de campo e análise de vouchers herbários, um total de cinco espécies de Cactaceae foram registrados: Brasiliopuntia brasiliensis (Pouco Preocupante), Cereus fernambucensis subsp. fernambucensis (Pouco Preocupante), Melocactus violaceus subsp. violaceus (Vulnerável), Pereskia aculeata (Pouco Preocupante) e Pilosocereus arrabidae (Quase Ameaçado). Morfologia da folha (quando presente) e dos cladódios, e presença ou ausência de cefálio são os caracteres mais úteis para as delimitações específicas. Chave de identificação, descrições, fotografias, comentários taxonômicos, distribuição geográfica e dados de habitat são fornecidos aqui.

Palavras-chave: Mata Atlântica, cactos, Caryophylalles, Restinga, taxonomia.

\section{Introduction}

Caryophyllales has 13 families sharing, among other synapomorphies, the presence of vessels with simple perforations and similar aminoacid sequences of the citrochrome $c$ (Judd et al. 2009; APG IV 2016). In the suborder Caryophyllineae, which is considered monophyletic based on morphological and molecular studies (Judd et al. 2009), Cactaceae and Portulacaceae are phylogenetically related by sharing loss of internal phloem and CAM photosynthetic metabolism (Judd et al. 2009; Ocampo \& Columbs 2010; Hernández-Hernández et al. 2011). Cactaceae, one of the most representative and iconic families of the order, has approximately 1,400 species and 100 genera distributed exclusively in the American continent, with Mexico, USA, and Northeastern and Southeastern Brazil bearing its main centers of diversity (Barthlott 1983; Valiente-Banuet et al. 1996; Dávila-Aranda et al. 2002; Casas et al. 2014).

\footnotetext{
${ }^{1}$ Universidade Federal do Espírito Santo - UFES/CEUNES, Lab. Sistemática e Genética Vegetal, São Mateus, ES, Brasil.

${ }^{2}$ ORCID: < https://orcid.org/0000-0002-4643-8177>.

${ }^{3}$ ORCID: <https://orcid.org/0000-0003-2829-5587>.

${ }^{4}$ ORCID: <https://orcid.org/0000-0001-5810-5145>.

${ }^{5}$ Author for correspondence: alvaronepomuceno567@gmail.com
} 
Cactaceae species are characterized mainly by the reduction of branches, leaves (usually) modified in spines, succulent and photosynthetic stems, superficial and often thorny roots (Duque 1980; Wallace \& Gibson 2002; Edwards \& Donoghue 2006; Judd et al. 2009). Due to their features, many species might be used as human food resource, forage, timber, medicinal and ornamental (Ruedas et al. 2006; Santos et al. 2007; Lucena et al. 2013, 2014; Nunes et al. 2015).

In Brazil, Cactaceae is represented by approximately 270 species (193 endemic) and 39 genera (14 endemic), which Pilosocereus Byles \& Rowley, Rhipsalis Gaertn. (29 spp., each) and Parodia Speg. (27 spp.) are the most taxonomically diverse genera (BFG 2018). The highest species richness can be found in arid and semi-arid environments, such as those occurring in Northeastern Brazil (Taylor \& Zappi 2004). However, many species can be also found in moist environments such as the Atlantic Forest where 102 species belonging to 21 genera are recorded (BFG 2018). Amongst Brazilian states, Rio de Janeiro is the one which bears the highest number of Cactaceae taxa recorded (57 spp.) (BFG 2018).

Identification of Cactaceae samples in herbaria is difficult due to the different methods of collection and drying specimens. Main reproductive characters of Cactaceae are lost during sampling and drying processes, especially those from fruits. In addition, the number of thorns in the areolas can also be modified depending on processes mentioned above.

Under these considerations, the present work aims to provide a taxonomic treatment for Cactaceae occurring in the State Park of Itaúnas, contributing to the knowledge of the regional and state floras, and delimitation among the species of the group.

\section{Materials and Methods}

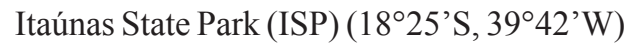
(Fig. 1) is located in the municipality of Conceição da Barra, northern coast of Espírito Santo, and has an area of 3,481 ha (Souza et al. 2016). The ISP is fully inserted in the geological zone of the trays and has several natural ecosystems, such as restingas (predominant vegetation), tabuleiro forests, dunes, wetlands and mangroves (Souza et al. 2016).

Specimens at VIES and SAMES herbaria (acronyms according to Thiers, continuously updated) were analyzed, and fieldwork expeditions were performed from August/2018 to May/2019. Samples were processed according to Peixoto \& Maia (2013), incorporated mainly to VIES herbarium and duplicates sent to MBML and SAMES herbaria. Identification and geographical distribution comments were performed using specialized literature (Zappi 1994; Taylor \& Zappi 2004; Hunt et al. 2006; Zappi et al. 2007; Menezes et al. 2013; Gonzaga et al. 2014a,b, 2017).

Terminology for morphological characters followed Harris \& Harris (2001) and Taylor \& Zappi (2004). Scientific names and their authorship are in agreement with IPNI (2019). Habit and habitat data were based on voucher tags information and field observations.

This work is part of the series of taxonomic and floristic works carried out for Itaúnas State Park, among them Souza et al. $(2016,2017)$ and others which will be published soon.

\section{Results and Discussion}

For the Espírito Santo, 46 species of Cactaceae are recorded, of which 22 occur in the restingas of the state, of these, five $(22 \%)$ species are recorded in the ISP (BFG 2018). In addition, of the 13 species of Cactaceae endemic to Brazil that occur in the capixaba restingas, four $(23 \%)$ are registered for study area (BFG 2018).

Initially, Cactaceae at the ISP was represented by six species (Souza et al. 2016), however, after the taxonomic treatment presented here, five species are recognized for the family: Brasiliopuntia brasiliensis (Willd.) A. Berger, Cereus fernambucensis Lem. subsp. fernambucensis, Melocactus violaceus Pfeiff. subsp. violaceus, Pereskia aculeata Mill. and Pilosocereus arrabidae (Lem.) Byles \& Rowley, being this the first taxonomic treatment considering Cactaceae from Espírito Santo state. Main useful morphological characters for species delimitation were the leaf cladodes morphology and presence or absence of cephalium.

According to the Goettsch et al. (2015), Brasiliopuntia brasiliensis, Cereus fernambucensis subsp. fernambucensis and Pereskia aculeata are assigned as Least Concern (LC), Pilosocereus arrabidae as Near Threatened (NT), and Melocactus violaceus subsp. violaceus as Vulnerable (VU). 

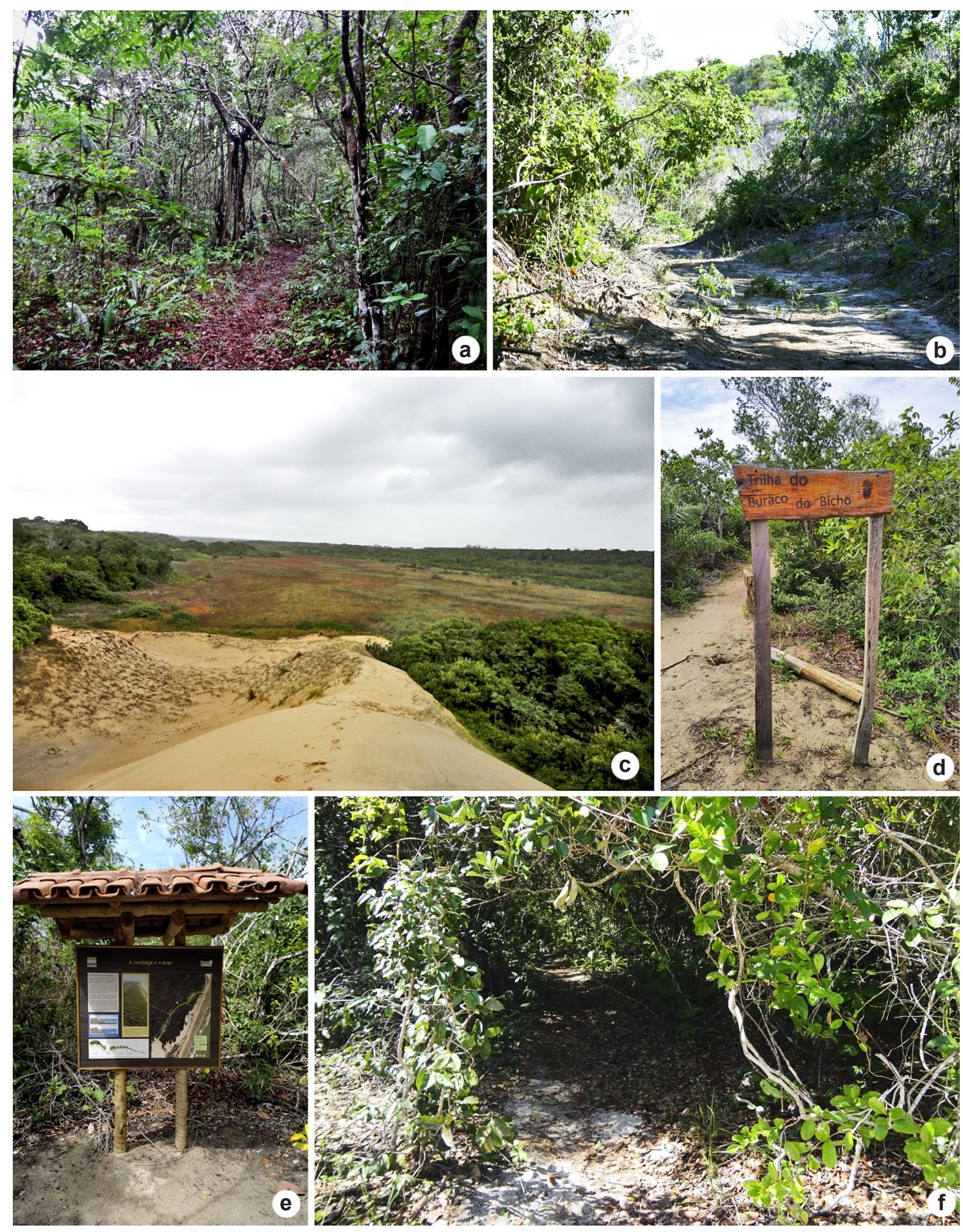

Figure 1 - a-f. Environments found in the Itaúnas State Park - a. Alméscar of Trail; b. Borboleta of Trail; c-d. Buraco do Bicho of Trail; e. Pescador of Trail; f. Restinga of Trail. 
Taxonomic treatment

\section{Identification key for the Cactaceae species of ItaúnasState Park}

1. Leaves well developed and functional present; pedicellate flowers and gathered in florescences 4. Pereskia aculeata

1'. Leaves reduced or transformed into spines; sessile flowers and lonely.

2. Arborescent; glochids present, cladodes dimorphics, reduced leaves (in young shoots)

1. Brasiliopuntia brasiliensis

2'. Shrubs; glochids absent, cladodes monomorphics, leaves transformed into spines.

3. Subglobose cladodes; present cephalium, flowers $1.5-2.5 \times 0.6-1.3 \mathrm{~cm}$, berry $10-16 \times 8-10$ mm...... 3. Melocactus violaceus subsp. violaceus

3'. Cylindrical cladodes; absent cephalium, flowers $6-20 \times 4-5 \mathrm{~cm}$, berry $3-7 \times 3.5-5.8 \mathrm{~cm}$.

4. Articulated cladodes, areoles well-spaced along the ribs.

2. Cereus fernambucensis subsp. fernambucensis

4'. Non-articulated cladodes, areoles congested along the ribs

5. Pilosocereus arrabidae

\section{Brasiliopuntia brasiliensis (Willd.) A. Berger.} Fig. 2a-b

Arborescent 4-5 m tall. Cladodes cylindrical, branched, articulated, ribs absent, intermediate segments $22-54 \mathrm{~cm}$ long, cylindrical, terminal segments 5-12 × 3-5 cm, compresses, obovate, deciduous, distal areolas $10-30 \mathrm{~mm}$ between each other, spinescent, spines 1-2, 5-20 mm long, glabrous. Glochids present. Leaves reduced (young branches) or absent (mature branches). Flowers appearing at the apex of the cladodes. Flowers 3-5 × 4-6 cm, sessile, near to terminal segments, filaments and anthers glabrous, ovary ovate, style $1.2-1.5 \mathrm{~mm}$ long, stigmatic branches 3-6, 3-6 mm long. Berry 3-6 cm diam., spinescent, globose, yellow-greenish pericarp, smooth, areolated. Seeds 8-10 × 7-9 mm, subgloboids.

Examined material: Trilha da Restinga, 7.VII.2012, fr., L.F.T. Menezes et al. 2037 (SAMES); 12.II.2014, fr., J.O. Machado et al. 200 (VIES); 2.IV.2019, fr., $A$. Nepomuceno et al. 795 (VIES).

Additional examined material: BRASIL. ESPÍRITO SANTO: Conceição da Barra, Área 126 da Aracruz Celulose, 26.II.1992, fr., O.J. Pereira et al. 2879 (VIES); Área 213 da Aracruz Celulose, 25.II.1992, fl., O.J. Pereira et al. 3099 (VIES).

Brasiliopuntia (K. Schum) A. Berger is a monospecific genus belonging to the tribe Opuntieae of the subfamily Opuntioideae, occurring from Bolivia to Paraguay and Argentina (Taylor \& Zappi 2004; Hunt et al. 2006). In Brazil, B. brasiliensis occurs in all phytogeographical domains, in Deciduous
Seasonal Forest, Semideciduous Seasonal Forest, Ombrophilous Forest, Mixed Ombrophylous Forest, restinga and rocky outcrops (BFG 2018). It is characterized by having dimorphic branches, compressed at the top and cylindrical at the base. The species is categorized as Least Concern (LC) according to Goettsch et al. (2015). In the study area, it is considered as rare where it can be found only on the edges of restinga forest.

2. Cereus fernambucensis Lem. subsp. fernambucensis.

Fig. 2c-d

Shrubs 1-2 m tall. Cladodes cylindrical, branched, articulate, 4-5 ribbed, ribs $1-2 \mathrm{~cm}$ high, oblique transverse folds, distal areolas 7-22 $\mathrm{mm}$ between each other, spinescent, spines 4-8, 5-30 mm long. Glochids absent. Leaves transformed in spines. Absent cephalium. Flowers 15-20 cm long, sessile, filaments and anthers glabrous, ovary ovate, style 16-18 cm long, stigmatic branches $12,5-10 \mathrm{~mm}$ long. Berry 5-7 $\times 3.5-5.5 \mathrm{~cm}$, glabrous, ovoid, pericarp pinkish to reddish, smooth. Seeds $2-3 \times 1.8-2$ $\mathrm{mm}$, suborbicular.

Examined material: Trilha da Borboleta, 2.VI.2019, fl., A. Nepomuceno et al. 788, 789 (VIES); Trilha do Pescador, 21.I.2013, fl., R. Coelho 255 (SAMES); 7.II.2013, fl., A.O. Giaretta 448 (VIES); 15.VIII.2013, fl., J.O.Machado et al. 133 (VIES).

Additional examined material: BRASIL. ESPÍRITO SANTO: Conceição da Barra, Área 126 da Aracruz Celulose, 3.XII.1992, fl., O.J. Pereira et al. 4343 (VIES); Área 213 da Aracruz Celulose, 4.XI.1992, fl., O.J. Pereira et al. 4102 (VIES). 

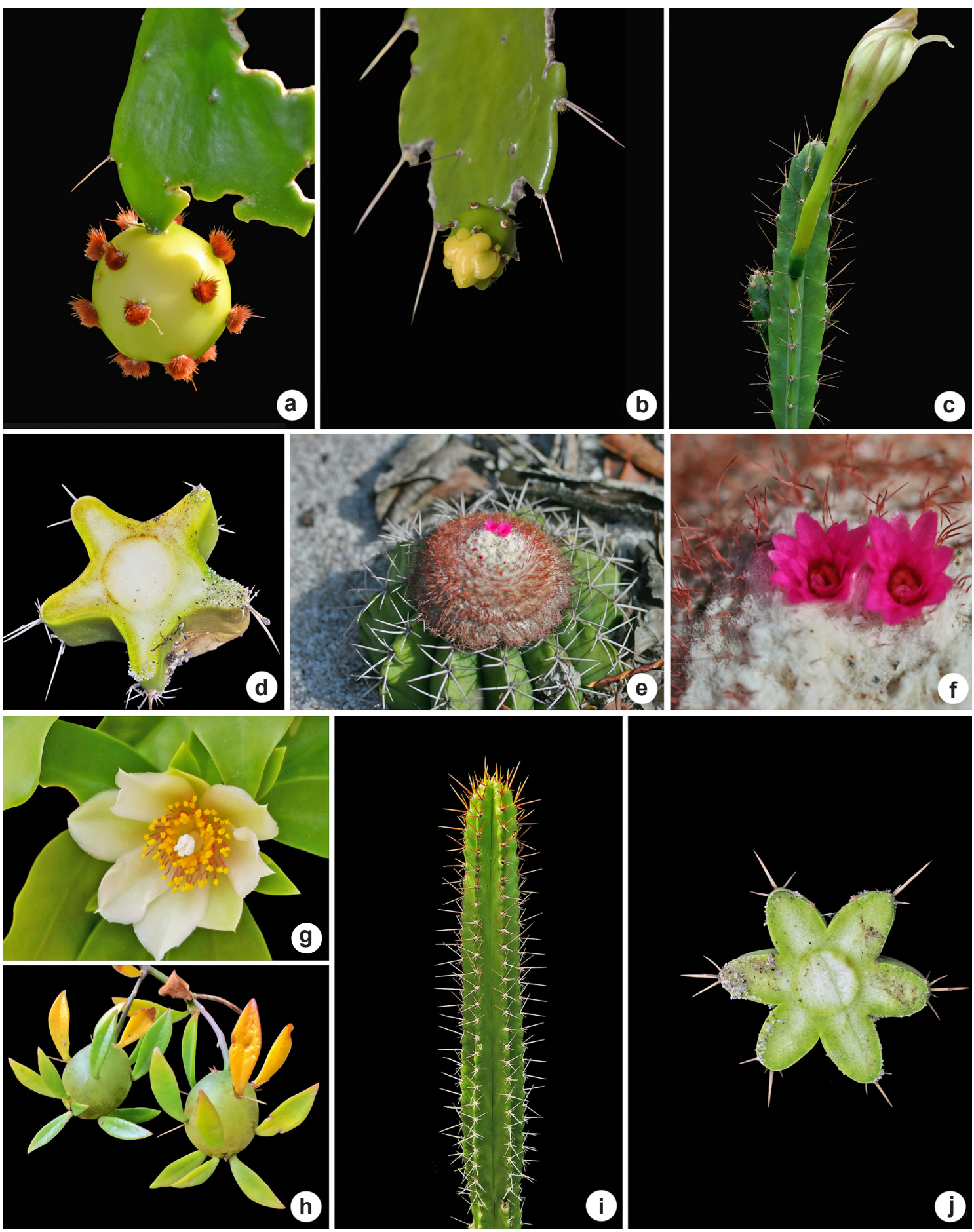

Figure 2 - a-j. Morphological characteristics of native Cactaceae from Itaúnas State Park - a-b. Brasiliopuntia brasiliensis - a. berry; b. floral bud; c-d. Cereus fernambucensis subsp. fernambucensis - c. cladode with flower; $\mathrm{d}$. cross section of cladode; e-f. Melocactus violaceus subsp. violaceus - e. apical cephalium; f. flowers; g-h. Pereskia aculeata - g. flower; h. berry; i-j. Pilosocereus arrabidae - i. cladode; j. cross section of cladode. Photographs: a-c. SGV files; d-e. Rafael Mathielo; f. SGV files; g-h. Maria Ana Farinaccio; i. SGV files; j. Rafael Mathielo. 
Cereus Mill. belongs to the Cereeae tribe of the subfamily Cactoideae and has ca. of 20 species distributed throughout South America (Taylor \& Zappi 2004). Cereus fernambucensis subsp. fernambucensis is endemic to Brazil and can be found Caatinga and Atlantic forest domains, in restingas and rocky outcrops (BFG 2018). The species differs from C. fernambucensis subsp. sericifer (Ritter) N.P. Taylor \& Zappi for presenting red fruits (vs. yellow) (Taylor \& Zappi 2004). In addition, it is assigned as Least Concern (LC) according to Goettsch et al. (2015). It can be found throughout study area, especially in open areas and forest edges.

\section{Melocactus violaceus Pfeiff. subsp. violaceus.}

Fig. 2e-f

Shrubs solitary $8-13 \mathrm{~cm}$ tall. Cladodes subglobose, non-branched, 9-13 ribbed, ribs 2-3.5 $\mathrm{cm}$ high, oblique transverse folds, distal areolas 5-10 $\mathrm{mm}$ between each other, spinescent, spines $10-12,15-25 \mathrm{~mm}$ long. Glochids absent. Leaves transformed in spines. Apical cephalium with white trichomes and spinning brown bristles. Flowers $1.5-2.5 \times 0.6-1.3 \mathrm{~cm}$; sessile, ovary ovate. Berry 10-16 × 8-10 mm, glabrous, claviforme, pericarp pink to off-white at the base, smooth. Seeds 1-1.5 $\times 0.8-1 \mathrm{~mm}$, ellipsoids.

Examined material: Trilha da Borboleta, 28.III.2009, fr., M.M. Monteiro 150 (SAMES), 14.IV.2014, fl., J.O. Machado et al. 307 (VIES).

Additional examined material: BRASIL. ESPÍRITO SANTO: Conceição da Barra, Área 213 da Aracruz Celulose, 25.II.1992, fl., O.J. Pereira 3099 (VIES); São Mateus, Bairro Litorâneo, 28.VIII.2008, fl., A.O.Giaretta et al. 322 (SAMES).

Melocactus (L.) Link. \& Otto belongs to the Cereeae tribe of the subfamily Cactoideae and has 34 species distributed from Mexico to the east of Brazil, with limit distribution in Rio de Janeiro (Taylor \& Zappi 2004). Melocactus violaceus is endemic in Brazil, occurring in the phytogeographic domains of Caatinga and Mata Atlântica, in carrasco and restinga vegetation (BFG 2018). It is distinguished from Melocactus violaceus subsp. margaritaceus N.P. Taylor for presenting fruits pink to purple (vs. white) and Melocactus violaceus subsp. ritteri N.P. Taylor due to occur in the coastal region of Brazil, mainly in restinga ( $v s$. occurrence restricted to the rocky outcrops of the interior of the Bahia state). The species is classified as vulnerable (VU) according to Goettsch et al. (2015). In the study area, the species is often found in open areas.

\section{Pereskia aculeata Mill.}

Fig. 2g-h

Climbing shrub. Cladodes cylindrical, branched, not articulated, ribs absent, spines 1-10 central, 10-30 mm long, 6-20 radial, 7-40 mm long, cylindrical. Leaves well-developed and functional, alternate, petiole 3-5 mm long, glabrous, lamina 2.5$7 \times 0.5-3 \mathrm{~cm}$, elliptic to narrow-elliptic, glabrous. Glochids absent. Inflorescences in panicles terminal and axillary. Flowers $2.5-5 \times 2-4 \mathrm{~cm}$, pedicels 5-20 mm long, ovary ovate, style $10-11 \mathrm{~mm}$ long, stigmatic branches 4-7, 3-5 mm long. Berry 1-2 cm diam, glabrous, globose, pericarp yellowish, smooth, spines 3-8 $\mathrm{mm}$ long, glabrous, cylindrical, bracts $8-15 \times 1-4 \mathrm{~mm}$, narrow-elliptic, glabrous. Seeds $4.5-5 \times 4-4.2 \mathrm{~mm}$, obovate to elliptical.

Examined material: Trilha da Restinga, 11.IV.2010, fr., M. Ribeiro 123 (SAMES, VIES); 22.III.2014, fl., B.S. Amorim et al. 1966 (VIES); 19.V.2014, fl., N.T.L.Pena 96 (VIES); 2.VI.2019, A. Nepomuceno et al. 794 (VIES). Additional examined material: BRASIL. ESPÍRITO SANTO: São Mateus, Bairro da Liberdade, 6.III.2008, fr., O.J. Pereira (SAMES); 5.IV.2008, fr., M.B. Faria et al. 157 (SAMES).

Pereskia Mill. belongs to the subfamily Pereskioideae and has 17 species distributed throughout the neotropics (Taylor \& Zappi 2004). In Brazil, Pereskia aculeata occurs in the various phytophysiognomies of the Caatinga, Cerrado, and Atlantic Forest domains (BFG 2018). It can be distinguished from other species by presenting climbing habit. The species is classified as of Least Concern (LC) according to Goettsch et al. (2015). In the study area, the species is rare, being found in the canopy and at the edges of forest.

\section{Pilosocereus arrabidae (Lem.) Byles \& Romley. \\ Fig. 2i-j}

Shrubs ca. $2 \mathrm{~m}$ tall. Cladodes cylindrical, branched, non-articulated, 6 ribbed, ribs $1.5-2.5$ $\mathrm{mm}$ high, oblique transverse folds, distal areolas 10-15 mm apart, spinescent, spines 4-10, 5-15 mm long, glabrous. Glochids absent. Leaves transformed in spines. Absent cephalium. Flowers 6-7 × 4-5 $\mathrm{cm}$, sessile, filaments and anthers glabrous, ovary obovate, stylet $45-50 \mathrm{~mm}$ long, stigmatic branches $9,6-10 \mathrm{~mm}$ long. Berry 3-5 $\times 5-5.8 \mathrm{~cm}$, glabrous, subgloboid, green pericarp to light red, smooth to slightly rough. Seeds $1.5-2 \times 1-1.3 \mathrm{~mm}$, ellipsoids. Examined material: Trilha da Borboleta, 7.II.2009, fl., A.O. Giaretta 448 (SAMES); 27.IX.2009, fl., A.O. Giaretta 638 (VIES); 21.I.2013, fr., R. Coelho 254 (SAMES); 2.IV.2019, fl. and fr., A. Nepomuceno et al. 786 (VIES). Trilha da Restinga, 2.IV.2019, fr., A. Nepomисеno et al. 796 (VIES). 
Additional examined material: BRASIL. ESPÍRITO SANTO: Conceição da Barra, Área 126 da Aracruz Celulose, 3.XII.1992, fl., O.J. Pereira et al. 4342 (VIES); Área 213 da Aracruz Celulose, 25.III.1992, fl., O.J. Pereira et al. 3081 (VIES).

Pilosocereus Byles \& G.D. Rowley belongs to the Cereeae tribe of the subfamily Cactoideae and has 37 species distributed from Mexico to Paraguay (Taylor \& Zappi 2004). Pilosocereus arrabidae is endemic to the Brazilian Atlantic Forest domain, in restinga vegetation and rocky outcrops (BFG 2018). According to Taylor \& Zappi (2004), it is morphologically related to Pilosocereus brasiliensis (Britton \& Rose) Backeb. subsp. brasiliensis, a sympatric species in Espírito Santo state, especially due to morphology of the areolas and the color of the epidermis. However, it can be distinguished by presenting acute floral buds ( $v s$. obtuse in Pilosocereus brasiliensis subsp. brasiliensis). The species is classified as almost threatened (NT) (Goettsch et al. 2015). It can be found throughout study area, especially in open areas and forest edges.

\section{Acknowledgments}

We are indebted to the organization which funded our research, FAPES process $n^{\circ} 525 / 2018$ capixaba researcher. The authors thank Rafael Mathielo and Maria Ana Farinaccio, for the photographs; and Mariana de Andrade Wagner, for the English review.

\section{References}

APG IV - Angiosperm Phylogeny Group (2016) An update of the Angiosperm Phylogeny Group classification for the orders and families of flowering plants: APG IV. Botanical Journal of the Linnean Society 181: 1-20.

Barthlott W (1983) Biogeography and evolution in neo- and palaeotropical Rhipsalinae. In: Kubitzki K (ed.) Dispersal and distribution. Verlag Paul Parey, Hamburg. Pp. 241-248.

BFG - The Brazil Flora Group (2018) Brazilian Flora 2020: innovation and collaboration to meet Target 1 of the Global Strategy for Plant Conservation (GSPC). Rodriguésia 69: 1513-1527.

Casas A, Camou A, Otero-Arnaiz A, Rangel-Landa S, Cruse-Sanders J, Solís L, Torres I, Delgado A, Moreno-Calles AI, Vallejo M, Guillén S, Blancas J, Parra F, Farfán-Heredia B, Aguirre-Dugua X, Arellanes Y \& Pérez-Negrón E (2014) Manejo tradicional de biodiversidad y ecossistemas en Mesoamérica: el Valle de Tehuacán. Investigación Ambiental 6: 23-44.
Dávila-Aranda P, Arias-Monte S, Lira-Saade R, Villaseñor JL \& Valiente-Banuet A (2002) Phytogeography of the columnar cacti (Tribe Pachycereeae) in México: a cladistic approach. In: Fleming T \& Valiente-Banuet A (eds) Columnar cacti and their mutualists. Evolution, ecology and conservation. The University of Arizona Press, Tucson. Pp. 25-41.

Duque JG (1980) O Nordeste e as lavouras xerófilas. $3^{\mathrm{a}}$ ed. Coleção Mossoroense, Mossoró. 265p.

Edwards EJ \& Donoghue MJ (2006) Pereskia and the origin of the cactos life form. American Naturalist 167: 777-793.

Goettsch B, Hilton-Taylor C, Cruz-Piñón G, Duffy JP, Frances A, Hernández HM, Inger R, Pollock C, Schipper J, Superina M, Taylot NP, Tognelli M, Abba AM, Arias S, Arreola-Nava HJ, Baker MA, Bárcenas RT, Barrios D, Braun P, Butterworth CA, Búrquez A, Caceres F, Chazaro-Basañez M, CorralDíaz R, Perea MV, Demaio PH, Barros WAD, Durán R, Yancas LF, Felger RS, Fitz-Maurice B, Fitz-Maurice WA, Gann G, Gómez-Hinostrosa C, Gonzales-Torres LR, Griffith MP, Guerrero PC, Hammel B, Heil KD, Hernández-Oria JG, Hoffmann M, Ishihara MI, Kiesling R, Larocca J, Luz JLL, Loaiza CR, Lowry M, Machado MC, Majure LC, Ávalos JGM, Martorell C, Maschinski J, Méndez E, Mittermeier RA, Nassar JM, NegrónOrtiz V, Oakley LJ, Ortega-Baes P, Ferreira ABP, Pinkava DJ, Porter JM, Puente-Martinez R, Gamarra JR, Pérez PS, Martínez ES, Smith M, Sotomayor JM, Stuart SN, Muñoz JLT, Terrazas T, Terry M, Trevisson M, Valverde T, Devender TRV, Véliz-Pérez ME, Walter HE, Wyatt AS, Zappi D, Zavala-Hurtado JA \& Gaston KJ (2015) High proportion of cactus species threatened with extinction. Nature 15142, 1: 1-7.

Gonzaga DR, Menini-Neto L \& Peixoto AL (2017) Cactaceae no Parque Nacional do Itatiaia, Serra da Mantiqueira, Brasil. Rodriguésia 68: 1397-1410.

Gonzaga DR, Zappi DC, Furtado SG \& Menini Neto L (2014a) Cactaceae no Parque Estadual de Ibitipoca, Minas Gerais Brasil. Boletim de Botânica da Universidade de São Paulo 32: 1-8.

Gonzaga DR, Zappi DC, Furtado SG \& Menini Neto L (2014b) Cactaceae na Serra Negra, Minas Gerais Brasil. Rodriguésia 65: 443-453.

Harris J \& Harris M (2001) Plant identification terminology - an illustrated glossary. $2^{\text {nd }}$ ed. Spring Lake Publishing, Payson. 260p.

Hernández-Hernández T, Hernández HM, De-Nova JA, Puente R, Eguiarte LE \& Magallón S (2011) Phylogenetic relationships and evolution of growth from in Cactaceae (Caryophyllales, Eudicotyledoneae). American Journal of Botany 98: 44-61.

Hunt D, Taylor NP \& Charles G (2006) The New Cactus Lexicon. 2 vols. DH Books, Milborne Port. 900p. 
IPNI (2019) The International Plant Names Index. Available at $<$ http://www.ipni.org $>$. Access on 23 march 2019.

Judd WS, Campbell CS, Kellogg EA, Stevens PF \& Donoghue MJ (2009) Cactaceae. In: Sistemática vegetal: um enfoque filogenético. $3^{\mathrm{a}}$ ed. Artmed, Porto Alegre. 612p.

Lucena CM, Carvalho TKN, Marín EA, Nunes EN, Oliveira RS, Melo JG, Casas A \& Lucena RFP (2014) Potencial medicinal de cactáceas en la región semiárida del Nordeste de Brasil. Gaia Scientia Volume Especial Populações Tradicionais: 36-50.

Lucena CM, Lucena RFP, Costa GM, Carvalho TKN, Costa GGS, Alves RRN, Pereira DD, Ribeiro JES, Alves CAB, Quirino ZGM \& Nunes EM (2013) Use and knowledge of Cactaceae in Northeastern Brazil. Journal of Ethnobiology and Ethnomedicine 62: 1-11.

Menezes MOT, Taylor NP \& Loiola MIB (2013) Flora do Ceará: Cactaceae. Rodriguésia 64: 757-774.

Nunes AT, Lucena RFP, Santos MV \& Albuquerque UP (2015) Local knowledge about fodder plants in the semi-arid region of Northeastern Brazil. Journal of Ethnobiology and Ethnomedicine 11: 1-12.

Ocampo G \& Columbus JT (2010) Molecular phylogenetics of suborder Cactinae (Caryophyllales), including insights into photosynthetic diversification and historical biogeography, American Journal of Botany 97: 1827-1847.

Peixoto AL \& Maia LC (2013) Manual de procedimentos para herbários. Universidade Federal de Pernambuco, Editora Universitária, Recife. 97p.

Ruedas M, Valverde T \& Zavala-Hurtado JA (2006) Analysis of the factors that affect the distribution and abundance of three Neobuxbaumia species (Cactaceae) that differ in their degree of rarity. Acta Oecologica 29: 155-164.
Santos GMM, Cruz JD, Bichara-Filho CC, Marques OM \& Aguiar CML (2007) Utilização de cactos (Cactaceae) como recurso alimentar por vespas sociais (Hymenoptera, Vespidae, Polistinae) em uma área de caatinga (Ipirá, Bahia, Brasil). Revista Brasileira de Zoologia 24: 1052-1056.

Souza WO, Machado JO, Tognella MMP \& AlvesAraújo A (2016) Checklist de Angiospermas do Parque Estadual de Itaúnas, Espírito Santo, Brasil. Rodriguésia 67: 571-581.

Souza WO, Pena NTL, Garbín ML \& Alves-Araújo A (2017) Macrófitas aquáticas do Parque Estadual de Itaúnas, Espírito Santo, Brasil. Rodriguésia 68: 1907-1919.

Taylor NP \& Zappi D (2004) Cacti of Eastern Brazil. Royal Botanic Gardens, Kew. 499p.

Thiers B [continuously updated] Index Herbariorum: a global directory of public herbaria and associated staff. New York Botanical Garden's Virtual Herbarium. Available at <http://sweetgum.nybg.org/ science/ih/>. Access on 23 march 2019.

Valiente-Banuet A, Arizmendi MC, Rojas-Martínez A \& Domínguez-Canseco L (1996) Ecological relationships between columnar cacti and nectarfeeding bats in Mexico. Journal of Tropical Ecology 12: 103-119.

Wallace RS \& Gibson AC (2002) Evolution and systematics. In: Nobel PS (ed.) Cacti: biology and uses. University of California Press, Berkeley. Pp. $1-21$.

Zappi DC (1994) Pilosocereus (Cactaceae). The genus in Brazil. Succulent Plant Research 3: 1-160.

Zappi DC, Aona LYS \& Taylor N (2007) Cactaceae. In: Wanderley MGL, Shepherd GJ, Melhem TS \& Giulietti AM (eds.) Flora fanerogâmica do estado de São Paulo. Instituto de Botânica, São Paulo. Vol. 5, pp. 163-193. 